\title{
The Heosemys Spinosa Monitoring Model in Conservation Areas as the Conservation Practicum for Postgraduate Science Education in Bengkulu University
}

\author{
Bhakti Karyadi*, Aceng Ruyani, Agus Sundaryono, Deni Parlidungan and Pani Aswin
}

Graduate School of Science Education, University of Bengkulu

*Corresponding author. Email: bkaryadi@unib.ac.id

\begin{abstract}
This study aims to develop a Heosemys Spinosa monitoring model to assist practicum activities on Conservation Education material. This type of research is a development to produce a turtle monitoring model in practical activities. The research location was conducted in the turtle conservation area of Bengkulu University. The research data were collected using survey techniques, observation and documentation. The instruments used include questionnaire sheets, observation sheets. The results of this study were a turtle monitoring model which consisted of four stages, namely (a) orientation by observing the location, tools and animals of the turtles; (b) exploration with turtle monitoring activities; (c) Interpretation through data analysis and verification; (d) translation, namely data visualization and mapping. Based on the research results, monitoring of Heosemys spinosa turtles can be used as material for conservation practice activities for postgraduate education at the University of Bengkulu.
\end{abstract}

Keywords: Heosemys spinosa, Monitoring model, Conservation practicum.

\section{INTRODUCTION}

Turtles are a type of wildlife in biodiversity in Indonesia, of which at least 39 species exist in Indonesia [1] In recent years, the demand for tortoises has increased, especially from China, Europe and the United States, both as pets and exotic foodstuffs [1] This of course can be a threat to its sustainability in nature. The most real threat to the natural population of turtles in Indonesia is hunting for trade and habitat destruction.

Bengkulu Province has several types of turtles that are scattered in almost all areas, especially those with fresh and terrestrial habitats. Distribution of freshwater and terrestrial turtles are found in Bengkulu Utara, Kepahiang, South Bengkulu, Seluma, and Mukomuko districts. In North Bengkulu district, there are four types of turtles, namely Notochelys Platinota, Cyclemys oldhamii, Cuora amboinensis, and Dogonia suplana. In Kepahiang district, there are four types of tortoises, namely C.oldhamii, Siebenrockiella crassicollis, Dogonia suplana, and Amyda cartilagenia. In Seluma district there are six types of turtles, namely C.oldhamii, Heosemys spinosa, Cuora amboinensis, Notochelys platynota, Monouria emys, and Dogonia suplana. In Mukomuko district, seven types of turtles were found consisting of Cuora amboinensis, C.oldhamii, Notochelys platinota, Dogonia suplana, Heosemys spinosa, Monouria emys, and Pelochelys cantorii [2].

One of the turtles that needs attention is the Turtle Tortoise (Heosemys spinosa). Native Indonesian animals that have unique characteristics can be seen from their sharp, pointed carapace at the marginal parts and small spines on the pleural scutes when they are still young but disappear when growing up. The distribution area of turtle are Sumatra, Kalimantan, and small islands around it including the Bangka Belitung, Riau, Natuna, and several other islands in Nias. The International Union for Conservation of Nature (IUCN) lists $H$. spinosa which is stated in the red list with the critical category as Endangered, the status of the Convention on International Trade In Endangered Species (CITES), namely: Appendix II (a status that states animals). The population of $H$. spinosa in Bengkulu province is quite alarming, animals are rarely found in their natural habitat [3]. This scarcity is due to the expansion of plantation land, pollution, and chemical waste from palm oil mills [2]. Without conservation efforts and laws that protect, it is possible that $H$. spinosa is increasingly under threat.

The University of Bengkulu (UNIB) is the only campus in Bengkulu that has a turtle conservation program with the "UNIB Campus a Safe Home For Turtles" program to support and make the UNIB campus a green and "safe home" for the development of turtle species. Monitoring the growth of $H$. spinosa while in the ex situ conservation area of Taman Pintar can help identify the presence of $H$. spinosa which is affected by disease, increase in size, death, and even the possibility of finding new individuals as a result of breeding that occurs naturally in the conservation area. In addition to monitoring growth and reproduction, it is also very important to know the home range of $H$. spinosa in the 
conservation area so as to know the condition of the H.spinosa microhabitat. H.spinosa Tortoise Monitoring Technique can be carried out in an integrated manner in conservation practicum activities for UNIB students.

The use of the conservation area as a place of preservation and learning resources is continuously carried out in a structured manner through academic activities, both lectures and researches. The practicum model integrated in the "UNIB Campus a Safe Home For Turtles" program in conservation activities needs to be continuously developed to find a more effective and efficient model. The practicum model is expected to increase students 'skills in turtle monitoring technique activities and build students' awareness of the importance of maintaining the sustainability of natural resources for future interests.

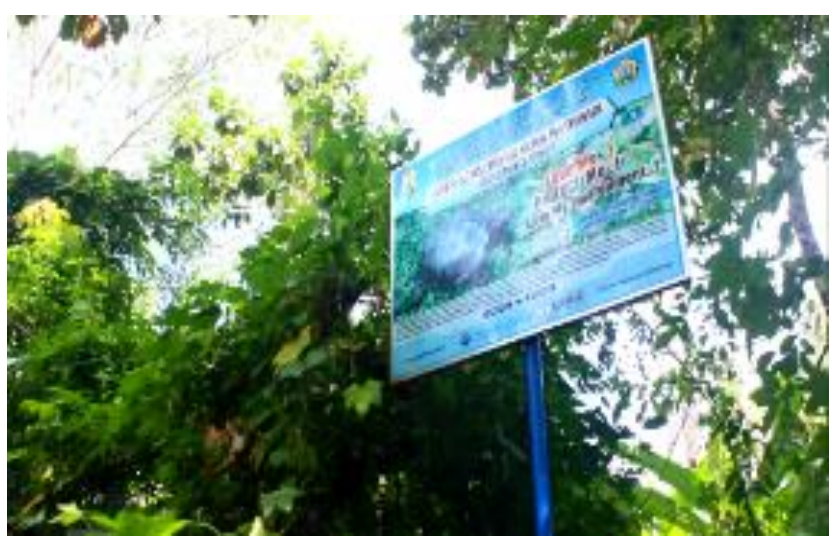

Figure 1. Turtle Learning Center

\section{RESEARCH METHODS}

The research was conducted from July to November 2020, taking place in the ex situ conservation area of the UNIB Sumatran turtle. The development of the practicum model refers to the 4-D development model which consists of 4 stages, namely Define, Design, Develop, and Disseminate [5] The research subjects involved 12 students of the $\mathrm{S} 1$ science education study program, FKIP UNIB.

The research began with a step in analyzing the syllabus of the conservation education course and practicum material related to that course. The step was done by observing the environmental conditions of the conservation area and the population of $H$. spinosa turtles in the conservation area. The next step was $\mathrm{s}$ designing a strategy for implementing turtle monitoring practicum in the conservation area and developing monitoring working procedures based on the tools used. The next step is the design of work models and procedures that have been designed to be implemented in practicum activities for students of the Science Education study program. Implementation was carried out through 3 meetings, the first meeting, conducting environmental orientation in the conservation area and introducing $\mathrm{H}$. spinosa tortoises and work procedures based on the equipment used. The second meeting analyzed monitoring data regarding the biological conditions and home range of H.spinosa. The results and the monitoring process of H.spinosa in the conservation area are presented in the form of a video as a practical model for monitoring H.spinosa turtles.

The result of development was analyzed descriptively by looking at the achievement of student performance in practicum activities. The findings in practicum activities were used as material evaluation and revisions to the H.spinosa monitoring practicum model in the conservation area.

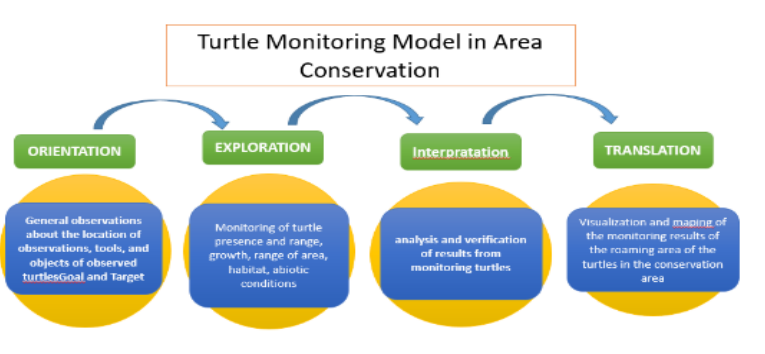

Figure 2. Turtle Monitoring Model

\section{RESULTS AND DISCCUSION}

\subsection{Conservation Area}

The ex-situ conservation area for Sumatran turtles has been developed since 2013 by the Master of Education Study Program with the support of the FKIP Dean and the Chancellor of UNIB. Conservation of the types of Sumatran turtles released in this area are the Broken Dada turtle (Cyclemys oldhamii), the Batok turtle (Coura amboinensis), and the White Cheek turtle (Siebenrockiella crassicollis), Baning turtle (Manouria emys), and Duri ( Heosemys spinosa). Several types of animals that are often found in conservation areas, the diversity of animals and plants in conservation areas and the completeness of field tools (practicum) that are available greatly support the environment-based learning process in the conservation area. Based on a study conducted, the ecosystem environment in the conservation area is quite supportive for conservation practicum activities for students. In the conservation area there is also the location of the Sumatran Turtle Conservation Study Center, this location as a collection of several types of Sumatran turtles. The description of the location conservation area which is the source of learning in this study is as follow us. This monitoring model is the theory and practice of observing turtles in the ex-situ conservation area of the Sumatran turtle species found on the campus of the University of Bengkulu (UNIB). The monitoring model was developed in conservation education lectures in the $\mathrm{S} 1$ and $\mathrm{S} 2$ Science Education study programs, FKIP UNIB. 
Table 1 . The phase of activities in this study

\begin{tabular}{|c|c|c|}
\hline Phase & Description & Image \\
\hline (Orientation) & $\begin{array}{l}\text { The orientation phase is environmental initiation, which } \\
\text { is the first step before making observations. The } \\
\text { practitioners are given general information about the } \\
\text { environment that is the location of the observation, } \\
\text { determining a safe and comfortable place to work or } \\
\text { discuss. the area where they work is given information. } \\
\text { The main activity at this step is to provide an } \\
\text { introduction to the practicum activities to be carried out } \\
\text { and the goals to be achieved. Broadly speaking, it can } \\
\text { be done }\end{array}$ & \\
\hline (Exploration) & $\begin{array}{l}\text { This stage is the longest stage when viewed from the } \\
\text { side of the implementation time. preparations prepare } \\
\text { completeness of tools and explain procedures and } \\
\text { provide motivation to the practitioner to work carefully } \\
\text { and precisely, and pay attention to work safety in } \\
\text { carrying out exploration. The main activity is } \\
\text { monitoring the home range and abiotic factors in the } \\
\text { conservation area, and other biotic components. }\end{array}$ & 8 \\
\hline (Interpetation) & $\begin{array}{l}\text { The activity in this step is to analyze and verify } \\
\text { monitoring data regarding the home range of the turtles } \\
\text { in the conservation area and its relationship with the } \\
\text { abiotic and biotic conditions in the conservation area. } \\
\text { verification and clarification, the data in the hope that } \\
\text { the data obtained is more accurate. The analysis } \\
\text { technique used is adjusted to the objectives to be } \\
\text { achieved. Provide reinforcement of important concepts } \\
\text { related to conservation theory and practice. }\end{array}$ & $\frac{1}{1}$ \\
\hline (Translation) & $\begin{array}{l}\text { The activity carried out is conducting visualization and } \\
\text { maping of the monitoring results of the turtle cruising } \\
\text { area in the conservation area, which begins with } \\
\text { clarification of the results of the analysis carried out by } \\
\text { taking into account the correctness of the concepts } \\
\text { obtained based on accountable references. Reflecting } \\
\text { on the benefits obtained after carrying out practicum } \\
\text { activities so that they are meaningful. }\end{array}$ & 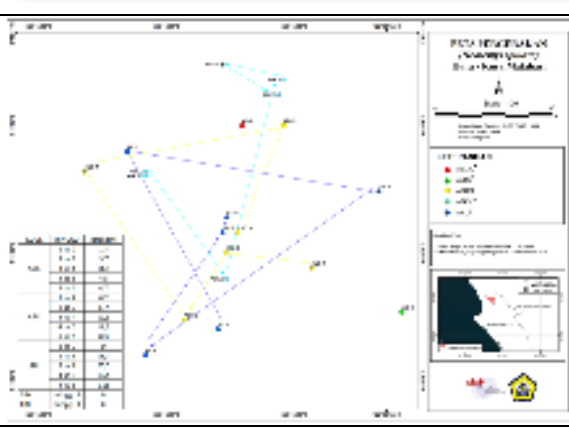 \\
\hline
\end{tabular}

Practical design of fire models, surveys, interpretation, and translation in conservation areas is expected to improve performance. Broadly speaking, the learning steps described describe practice-centered learning. Practical learning activities can encourage creativity and motivate students to learn independently
[4]. High motivation will encourage curiosity about an object (concept). The assimilation process of the participants' understanding is easier with high learning motivation [9] [10].

The monitoring model is oriented towards a scientific approach that can provide understanding to the 
practitioner in knowing, understanding various materials using a scientific approach. Learning with a psychological approach encourages the practitioner to find out from various sources. The application of the scientific approach to learning involves process skills, such as observing, classifying, measuring, predicting, explaining, and concluding. Based on its characteristics, the application of the monitoring model can be varied with the Problem Based Learning (PBM), discovery, and inquiry models. Referring to the scientific approach, the development of a monitoring model is closely related to the learning activities of the scientific approach.

The practicum model for monitoring outdoor learning based on the surrounding natural environment conceptually encourages learning that is environmentally sound ("Teaching Green"), namely facilitators who have the ability to develop learning that creates good relationships between the practitioner and the environment, and fosters concern for the environment [7].

The monitoring practicum framework developed involves the practitioner actively learning in constructing knowledge through a problem-solving and investigative approach. Learning by solving problems in context, fosters the attractiveness of the practitioner to the material and encourages student interest in a subject matter. Through problem solving students will construct their own knowledge during the learning process and gain understanding of the concept through interactions between external and external factors or the environment. The learning that is carried out does not only emphasize mastery of concepts, but forms the mindset and attitudes of students to care more about the environment, and be able to apply the principles of environmental sustainability. In this learning, the practitioner is directed to understand the environment by introducing environmental conditions, observing environmental phenomena, and responding appropriately to environmental problems based on the results of his exploration.

The inquiry learning model (inquiry) in exploratory activities invites students to be actively involved both physically and mentally in learning. Students are invited to actively think to identify problems, investigate to find answers to the problems faced until they reach conclusions. Thus in inquiry learning students are actively involved in the process of finding answers to problems or questions. States that the inquiry learning cycle are include three elements that must be passed, namely exploration, invention or concept development, and discovery application [6]. Further explains that learning by inquiry can improve intellectual abilities, increase intrinsic and extrinsic motivation, and can also encourage students to learn more actively. The emergence of intrinsic and extrinsic motivation will cause increased enthusiasm or enthusiasm and awareness of students.
Learning that presents phenomena or facts found in the environment around students will encourage students to learn contextually. Contextual learning can always connect or apply the material discussed with the practical realities it finds in everyday life around the environment of students. With this contextual learning, students will find a relationship between abstract ideas and practical (applicable) things in a real context, and internalize the concept through the discovery process [8] (Mooji Ton, 2013).

The contextual approach assumes that naturally a person's mind will look for meaning that is in accordance with the real environmental situation and provides benefits to the environment. Combining subject matter with students' daily experiences will produce a foundation of in-depth knowledge. Students will be able to use their knowledge to solve new problems that they have never faced. Through contextual approaches, it is hoped that students can build knowledge that can be applied in everyday life based on their learning experiences. Contextual Learning is a conception of learning that links the subject being studied with real situations, so that students will be able to apply their knowledge in everyday life.

Referring to the theoretical study of the monitoring practicum model, it can develop critical thinking skills (critical thinking), creative (creative), communicative (communicative), and able to work together (collaborative). The implementation of the monitoring practicum model developed creates a new perspective on the environment (new environmental paradigm) in the practitioner. A positive paradigm for the environment will have a tendency to participate in environmental conservation in general.

\section{CONCLUSION}

The monitoring practice model for $\mathrm{H}$. Spinosa's tortoise was designed in four steps, namely orientation, exploration, interpretation and translation. Each of these steps contains activities that must be carried out by the practitioner and supervisor in carrying out practicum. The steps in the practicum model can technically be carried out by the practitioner.

\section{ACKNOWLEDGMENTS}

This research is supported by the faculty of teaching and learning quality improvement education by the Graduate School of Science Education 2020. We give love to our colleagues from Science education who have provided insight and greatly assists research and greatly assists research.

\section{REFERENCES}

[1] Iskandar, D.T. (2000) Kura-kura dan Buaya Indonesia dan Papua Nugini dengan Catatan Mengenai Jenis-jenis di Asia Tenggara. Bandung (ID): PAL MediaCitra. 
[2] Putri, Y.A., Ruyani, A dan Muslim, C. (2011) Studi Biodistribusi Kura-kura Air Tawar dan Terestrial di Kabupaten Mukomuko serta Implementasi Model Pembelajaran Kooperatif Tipe Think, Pair, Square (TPSQ) dengan Menggunakan LKS pada Siswa SMPN 14 Mukomuko, Bengkulu [Thesis]. Bengkulu (ID). Universitas Bengkulu.

[3] Karyadi B., Aceng Ruyani., Agus Susanta., 2016.c. Development of a Learning Model for Enviromental Education at Ex-Situ Sumatran Turtle Conservation Ares. Proceeding International Seminar on Science Education (ISSE), Nurturing innovative and highly literate generation trough science education. Graduate School Yogyakarta State University. Vol 2. ISSN 2476-9533.

[4] Arends R. 2004. Learning to Teach, New York: Mc.Graw-Hill Book Company. CITES. (2017)
Appendices I, II and III valid from March 2016.

[5] Thiagarajan, S., Semmel, D. S., and Semmel, M. I. (1974) Instructional for Training Teachers of Exceptional Children. Minnesota: Center for Innovation in Teaching the Handicapped.

[7] Grant, T and Littlejohn, G. 2009, Teaching GreenThe High School Years: Hands-on Learning in Grades 9-12, Toronto: Green Teacher.

[8] Mooij. T. 2007. Contextual learning theory, Concrete form and a software prototype to improve early education, JournalComputers \& Education

[9] Lin, Ming-Hung, and Huang-G. Chen. "A study of the effects of digital learning on learning motivation and learning outcome." Eurasia Journal of Mathematics, Science and Technology Education 13.7 (2017): 3553-3564.

[10] Anderman, Eric M., and Heather Dawson. "Learning with motivation." Handbook of research on learning and instruction 219214 (2011). 